\title{
Selective Removal of Alkali Metal Cations from Multiply-Charged lons via Gas-Phase Ion/Ion Reactions Using Weakly Coordinating Anions
}

\author{
Carl A. Luongo, ${ }^{1}$ Jiexun Bu, ${ }^{1}$ Nicole L. Burke, ${ }^{1}$ Joshua D. Gilbert, ${ }^{1}$ Boone M. Prentice,${ }^{1}$ \\ Steven Cummings, ${ }^{2}$ Christopher A. Reed, ${ }^{2}$ Scott A. McLuckey ${ }^{1}$ \\ ${ }^{1}$ Department of Chemistry, Purdue University, West Lafayette, IN 47907-2084, USA \\ ${ }^{2}$ Department of Chemistry, University of California Riverside, Riverside, CA 92521, USA
}

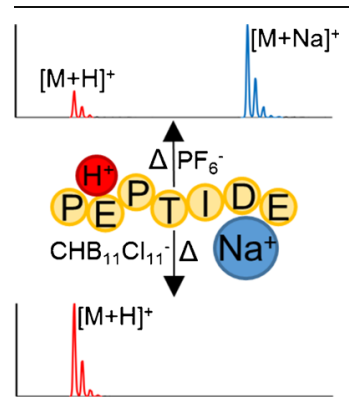

\begin{abstract}
Selective removal of alkali metal cations from mixed cation multiplycharged peptide ions is demonstrated here using gas-phase ion/ion reactions with a series of weakly coordinating anions (WCAs), including hexafluorophosphate $\left(\mathrm{PF}^{6-}\right)$, tetrakis[3,5-bis(trifluoromethyl)phenyl]borate (BARF), tetrakis(pentafluorophenyl)borate (TPPB), and carborane $\left(\mathrm{CHB}^{11} \mathrm{Cl}^{11-}\right)$. In all cases, a long-lived complex is generated by dication/anion condensation followed by ion activation to compare proton transfer with alkali ion transfer from the peptide to the anion. The carborane anion was the only anion studied to undergo dissociation exclusively through loss of the metallated anion, regardless of the studied metal adduct. All other anions studied yield varying abundances of protonated and
\end{abstract} metallated peptide depending on the peptide sequence and the metal identity. Density functional theory calculations suggest that for the WCAs studied, metal ion transfer is most strongly favored thermodynamically, which is consistent with the experimental results. The carborane anion is demonstrated to be a robust reagent for the selective removal of alkali metal cations from peptide cations with mixtures of excess protons and metal cations.

Keywords: Coded aperture sector mass spectrometry, Computational mass spectrometry, Miniature mass spectrometry

Received: 15 October 2014/Revised: 14 November 2014/Accepted: 15 November 2014/Published Online: 6 January 2015

\section{Introduction}

$\mathrm{W}$ idely employed ionization methods for non-volatile, thermally labile compounds [e.g., electrospray ionization and matrix-assisted laser desorption ionization (MALDI)], commonly generate positive ions with one or more excess small cation adducts, usually protons and/or alkali cations. Mixtures of excess cations are particularly common in the case of ESI, which tends to generate multiply-charged ions. The identities of the adduct ions obviously play a role in determining molecular mass and can also play roles in signal levels [1, 2] and spectral complexity [3] if there are mixtures of cations.

Electronic supplementary material The online version of this article (doi:10.1007/s13361-014-1052-3) contains supplementary material, which is available to authorized users.

Correspondence to: Scott A. McLuckey; e-mail: mcluckey@purdue.edu
Furthermore, metal-cationized analytes have been shown to favor different fragmentation routes upon collisional-induced dissociation (CID) than their protonated analogues [4, 5]. Metal adduction is a ubiquitous phenomenon as low concentrations of salts are often present in the background even when analytical grade solvents are used [1].

Several methods based on altering ionization conditions have been developed to influence the cation distribution present in analyte ions in ESI. The size of the ESI capillary can be decreased to effect nano-ESI (nESI), which has been shown to improve salt tolerance by approximately one order of magnitude [6]. Techniques implemented prior to ESI-MS, such as liquid chromatography [7, 8], ion exchange [9], solid phase extraction [10], and dialysis [11,12] have been shown to aid in salt removal; however, these methods add both time and complexity to the experiment. Vapor exposure [13] and solution additives $[3,14]$ have also been demonstrated to minimize metal cation adduction. 
Approaches to alter charge state distributions and, consequently, the relative excess cation composition of an analyte ion after ion formation have involved either ion/molecule or ion/ion reactions. Proton transfer ion/molecule reactions have been used to alter charge state distributions [15, 16], although selective removal of alkali ions in the presence of excess protons using ion/molecule chemistry has not been reported to our knowledge. Gas-phase ion/ion reactions have been shown to be particularly effective in transforming ions from one type to another $[17,18]$. Such ion transformations include, inter alia, acid/base reactions (i.e., proton transfer) $[19,20]$, reduction/oxidation reactions (i.e., electron transfer) [21-23], incorporation of metal ions into peptides (i.e., metal transfer) $[24,25]$, and covalent [26-28] and/or electrostatic modification $[29,30]$. Prior experience has shown that the large majority of anions that remove protons from multiply-protonated species tend not to remove alkali cations when both excess protons and excess alkali ions are present. We noted in previous work an exceptional case in which ion/ion reactions between the weakly coordinating anion (WCA) hexafluorophosphate $\left(\mathrm{PF}_{6}{ }^{-}\right)$and mixed protonated/metallated dications resulted in the removal of some sodium adducts though proton removal was present as a competing process [31].

The motivation in this work is to identify an anionic reagent that shows high selectivity for metal ion removal. Therefore, other WCAs, which are characterized by low proton affinities such that the conjugate acids are often referred to as 'superacids,' have been evaluated as selective reagents for metal cation removal from multiply-charged analytes. Weakly coordinating anions fall into a variety of compound classes, such as oxyanions, fluoroanions, tetraarylborates, carbanions, bis(perfluorosulfonyl)imides, polyoxometalates, and carboranes [32, 33]. The WCAs investigated here are $\mathrm{PF}_{6}^{-}$, the tetrakis[3,5-bis(trifluoromethyl)phenyl]borate anion (BARF), the tetrakis(pentafluorophenyl)borate anion (TPPB), and the carborane anion $\left(\mathrm{CHB}_{11} \mathrm{Cl}_{11}{ }^{-}\right.$) [34] (Figure $1 \mathrm{~b}-\mathrm{e}$, respectively). Deprotonated benzene sulfonic acid ([BMSA $\mathrm{H}^{-}$) (Figure 1a) [30], a non-WCA, was also included in the study as an example of a reagent that typically shows proton transfer and that generates intact ion/ion complexes. The generation of ion/ion complexes is desirable for the determination of relative tendencies for proton versus metal ion transfer because each complex can be subjected to roughly similar ion activation conditions, which minimizes ambiguities that might arise because of unknown differences in internal energies of the ion transfer intermediates.

\section{Methods}

\section{Mass Spectrometry}

All experiments were performed on a QTRAP 4000 hybrid triple quadrupole/linear ion trap (LIT) mass spectrometer (AB SCIEX, Concord, ON, Canada), previously modified for ion/ ion reactions [35]. Singly charged reagent anions and multiplycharged peptide cations were independently ionized using alternately-pulsed nano-electrospray (nESI) emitters [36], isolated in the Q1-mass filter and sequentially introduced into the $\mathrm{q} 2$ reaction cell. While in $\mathrm{q} 2$, the ions underwent a defined mutual storage ion/ion reaction period of $80 \mathrm{~ms}-1 \mathrm{~s}$, allowing for a substantial amount of the electrostatic complex to be formed. The ion/ion reaction complex was then transferred to Q3 LIT for further isolation and CID via resonant excitation. The products were mass-analyzed via mass-selective axial ejection (MSAE) [37].

\section{Calculations}

In order to reduce computational time, full geometry optimization and harmonic frequency calculations were not performed on all of the lysine-, histidine-, and arginine-containing peptides interrogated experimentally. Instead, calculations were performed on simplified model dibasic systems: a diamine, a diimidizole, and a diguanidine, respectively. Comparison between the diamine calculations and calculations on one of the experimentally studied peptides, KAKAKAA, validates the choice of using these simplified dibasic model systems for the computational work. Geometry optimization and harmonic frequency calculations were carried out using the Gaussian09 program to calculate the zero point energies at the B3LYP/6$31+\mathrm{G}(\mathrm{d})$ level of theory for the diamine, diimidizole, diguanidine, KAKAKAA, [BMSA $-\mathrm{H}^{-}, \mathrm{PF}_{6}{ }^{-}$, and $\mathrm{CHB}_{11} \mathrm{Cl}_{11}{ }^{-}$systems [38]. For the model systems and the smaller reagent anions, the molecules were small enough to not require a conformational search prior to geometry optimization. For the largest of the reagent anions, $\mathrm{CHB}_{11} \mathrm{Cl}_{11}{ }^{-}$, the structure previously determined by Kass et al. [39] was used for geometry optimization. Prior to the geometry optimization of
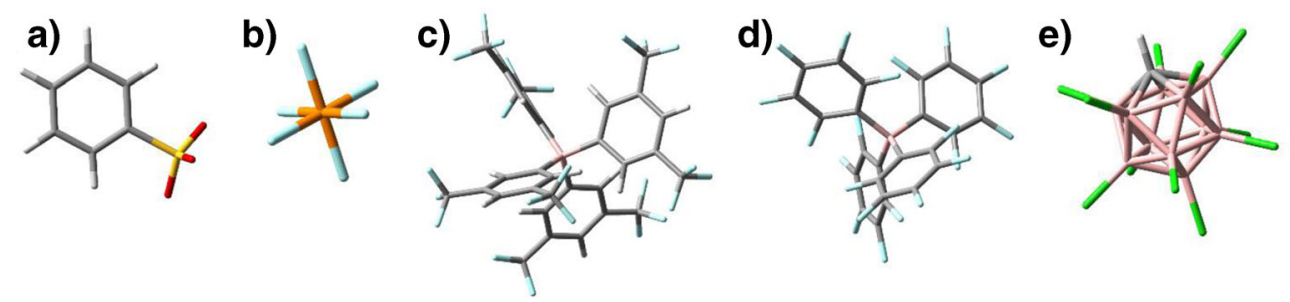

Figure 1. Stick structures of (a) [BMSA - H] $]^{-}$, (b) $\mathrm{PF}_{6}{ }^{-}$, (c) $\mathrm{BARF}^{-}$, (d) $\mathrm{TPPB}^{-}$, and (e) $\mathrm{CHB}_{11} \mathrm{Cl}_{11}{ }^{-}$. Gray represents carbon, white: hydrogen, yellow: sulfur, red: oxygen, orange: phosphorous, blue: fluorine, pink: boron, and green: chlorine 
the full peptide KAKAKAA, a conformational search was performed with the MACROMODEL suite of programs to generate a set of starting structures [40]. The Amber* force field was used to find stable minima within a $50 \mathrm{~kJ} / \mathrm{mol}$ window of the global minimum [41]. The five lowest energy structures were then optimized using density functional theory, with the lowest energy one being used for the numerical comparisons presented here. For the proton/sodium transfer reactions of the model diamine with $\mathrm{PF}_{6}^{-}$and $\mathrm{CHB}_{11} \mathrm{Cl}_{11}{ }^{-}$, the freezing string method [42] [B3LYP/6-31+G(d)] was used to locate the reaction paths in Q-Chem 4.0 [43]. The highest energy node from each pathway is taken as an approximation for the transition state energies.

\section{Materials}

Methanol was purchased from Mallinckrodt (Phillipsburg, NJ, USA). Bradykinin (RPPGFSPFR) was purchased from Bachem Americas Inc. (King of Prussia, PA, USA). Model peptides KAKAKAA, HAHAHAA, and RARARAA were synthesized by Pepnome Ltd. (Shenzhen, China). Lithium chloride, sodium chloride, potassium chloride, cesium chloride, the sodium salt of benzene sulfonic acid (BMSA), ammonium hexafluorophosphate $\left(\mathrm{PF}_{6}{ }^{-}\right)$, sodium tetrakis[3,5bis(trifluoromethyl)phenyl]borate (BARF), and lithium tetrakis(pentafluorophenyl)borate ethyl etherate (TPPB) were purchased from Sigma Aldrich (St. Louis, MO, USA). The cesium salt of carborane, $\mathrm{Cs}\left(\mathrm{CHB}_{11} \mathrm{Cl}_{11}\right)$, was synthesized [44] by Professor C. A. Reed's group of the Department of Chemistry, University of California, Riverside. All peptide stock solutions for positive nanoelectrospray were prepared in a 49.5/49.5/1 ( $\mathrm{vol} / \mathrm{vol} / \mathrm{vol})$ solution of water/methanol/metal chloride salt at an initial concentration of $\sim 1 \mathrm{mg} / \mathrm{mL}$ and diluted 100-fold prior to use. The solutions containing anions of $[\mathrm{BMSA}-\mathrm{H}]^{-}, \mathrm{PF}_{6}^{-}, \mathrm{BARF}, \mathrm{TPPB}$, and $\mathrm{CHB}_{11} \mathrm{Cl}_{11}{ }^{-}$were prepared in a $50 / 50$ (vol/vol) solution of water/methanol at a concentration of $\sim 1 \mathrm{mg} / \mathrm{mL}$ and diluted 10 -fold prior to use.

\section{Results and Discussion}

\section{Tandem Mass Spectrometry Data}

Collision-Induced Dissociation (CID) of Peptide Dication/ Anion Complexes The CID spectra of the complexes of doubly protonated bradykinin, [RPPGFSPFR $+2 \mathrm{H}]^{2+}$, with the various acids are shown in Figure $2 \mathrm{a}-\mathrm{e}$, along with the CID spectrum of [RPPGFSPFR $+\mathrm{H}]^{+}$in Figure 2f. These benchmark spectra are included to illustrate that peptide fragmentation from the peptide ion can compete with proton transfer when the proton affinity of the anion is low. As the anion proton affinity decreases, the barrier to proton transfer from the complex increases, which allows for peptide cleavages to become competitive. The proton affinities of the anions in this study are expected to follow the trend $[\mathrm{BMSA}-\mathrm{H}]^{-}>\mathrm{PF}_{6}{ }^{-}>\mathrm{BARF}>\mathrm{TPPB}>\mathrm{CHB}_{11} \mathrm{Cl}_{11}{ }^{-}$(these values have been calculated for $[\mathrm{BMSA}-\mathrm{H}]^{-}, \mathrm{PF}_{6}^{-}$, and $\left.\mathrm{CHB}_{11} \mathrm{Cl}_{11}{ }^{-}\right)$. In the cases of the complexes of [BMSA $\left.-\mathrm{H}\right]^{-}$ (Figure 2a) and $\mathrm{PF}_{6}^{-}$(Figure 2b), essentially no fragmentation of the peptide is seen either to compete with or follow proton transfer. However, with the complexes of the anions of BARF, $\mathrm{TPPB}$, and the carborane (Figure 2c-e), extensive fragmentation of the peptide is observed. The CID spectrum of

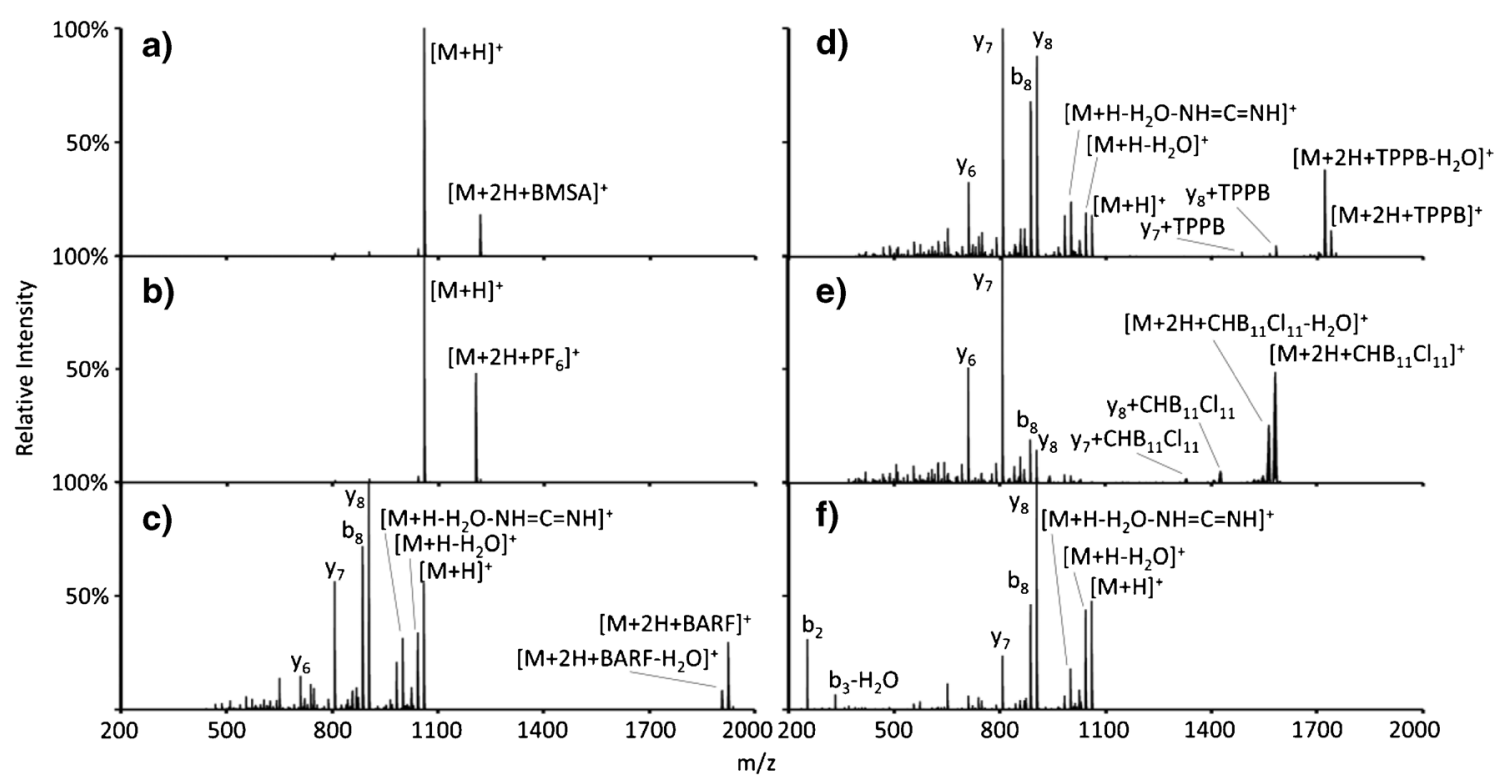

Figure 2. Ion trap CID spectra of the complex between doubly protonated bradykinin ([RPPGFSPFR $+2 \mathrm{H}]^{2+}$ ) and (a) $\left[\mathrm{BMSA}-\mathrm{H}^{-}\right.$, (b) $\mathrm{PF}_{6}{ }^{-}$, (c) $\mathrm{BARF}^{-}$, (d) $\mathrm{TPPB}^{-}$, and (e) $\mathrm{CHB}_{11} \mathrm{Cl}_{11}{ }^{-}$(f) Ion trap CID spectrum of the [RPPGFSPFR+H] ${ }^{+}$ion. In all cases, precursor ions were held at comparable $q_{z}$ values, such that the low mass cut-off values for the data of (c), (d), and (e) precluded storage of the $b_{2}$ and $\mathrm{b}_{3}-\mathrm{H}_{2} \mathrm{O}$ products noted in (f) 
$[\mathrm{RPPGFSPFR}+\mathrm{H}]^{+}$, given in Figure $2 \mathrm{f}$, shows that the peptide fragments generated from the complexes are generally those noted from CID of the protonated molecule. Note that essentially no intact proton transfer product (viz., the $[\mathrm{M}+\mathrm{H}]^{+}$ion) is observed from the dissociation of the complex with the carborane anion.
CID of bradykinin dications with an excess proton and a lithium cation, $[\mathrm{RPPGFSPFR}+\mathrm{H}+\mathrm{Li}]^{2+}$, complexed with the various acids yielded the results of Figure $3 \mathrm{a}-\mathrm{e}$. Proton transfer dominates for both [BMSA $-\mathrm{H}]^{-}$and $\mathrm{PF}_{6}^{-}$(Figure $3 \mathrm{a}$ and $\mathrm{b}$, respectively) with very little peptide fragmentation. In the case of the BARF anion (Figure 3c), proton transfer is again noted,

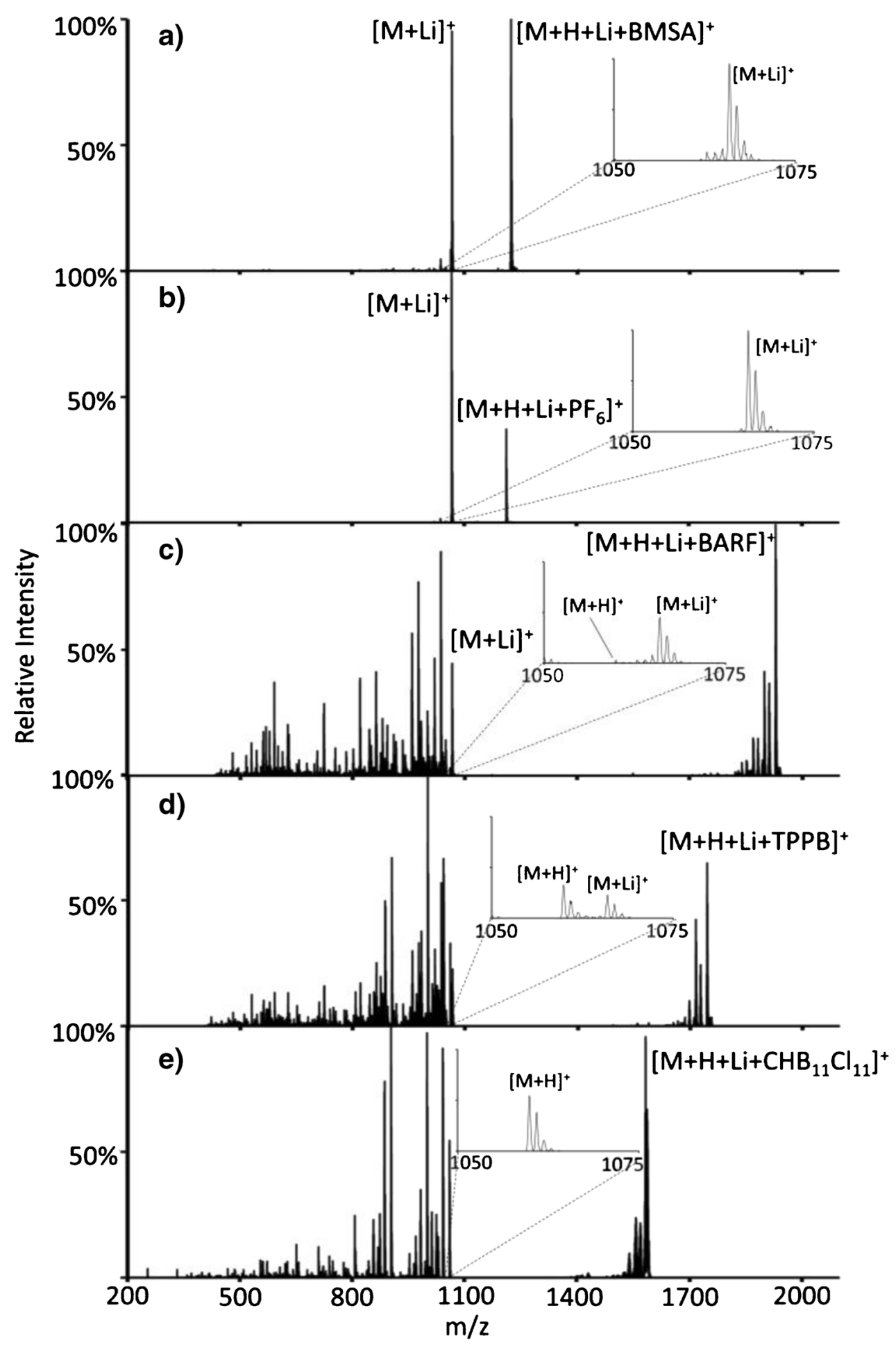

Figure 3. Resonant excitation of the complex between protonated and lithiated bradykinin ([RPPGFSPFR+H+Li $\left.]^{2+}\right)$ and $(\mathbf{a})[B M S A-$ $\mathrm{H}]^{-}$, (b) $\mathrm{PF}_{6}^{-}$, (c) $\mathrm{BARF}^{-}$, (d) $\mathrm{TPPB}^{-}$, and (e) $\mathrm{CHB}_{11} \mathrm{Cl}_{11}{ }^{-}$ 
as reflected in the appearance of the $[\mathrm{M}+\mathrm{Li}]^{+}$ion, with only a very small lithium transfer product, along with extensive peptide fragmentation. In the case of the TPPB anion, both proton and lithium ion transfer are observed, as reflected in the appearance of the $[\mathrm{M}+\mathrm{Li}]^{+}$and $[\mathrm{M}+\mathrm{H}]^{+}$ions, respectively, along with extensive peptide fragmentation. Both lithium and proton bearing b-type and y-type ions appear in the peptide fragments from complexes of the latter two ions. Supplemental Chart 1 provides a more extensive listing of peak assignments. For the carborane anion, however, no $[\mathrm{M}+\mathrm{Li}]^{+}$signal is observed. Rather, a significant $[\mathrm{M}+\mathrm{H}]^{+}$ion from lithium ion transfer is noted, along with extensive peptide ion dissociation. Very little evidence for the presence of lithium ions is present in the peptide fragments from the carborane-containing complex. These results are consistent with the presence of relatively low barriers for proton transfer in the cases of [BMSA $-\mathrm{H}]^{-}$ and $\mathrm{PF}_{6}{ }^{-}$. Proton transfer also occurs for the BARF and TPPB anions but the appearance of extensive peptide fragmentation indicates that the barriers to proton transfer for these two anions are higher than those for the complexes with [BMSA $-\mathrm{H}]^{-}$and $\mathrm{PF}_{6}{ }^{-}$. Only in the cases of the TPPB and carborane anions is lithium cation transfer observed and only in the case of the carborane anion is proton transfer absent.

The data of Figure 4 depict the behavior noted for the $[\mathrm{RPPGFSPFR}+\mathrm{H}+\mathrm{Na}]^{2+}$ ion. Activation of the complex formed between deprotonated BMSA and the bradykinin cation results in exclusive proton removal to yield the $[\mathrm{M}+\mathrm{Na}]^{+}$ species (Figure 4a). The first of the WCA/peptide complexes studied, $\left[\mathrm{M}+\mathrm{H}+\mathrm{Na}+\mathrm{PF}_{6}\right]^{+}$, displays both dissociative pathways upon CID, with the proton removal pathway being more favorable (Figure 4b). Both dissociation pathways are observed for resonant excitation of the complex formed between the peptide and $\mathrm{BARF}^{-},\left([\mathrm{M}+\mathrm{H}+\mathrm{Na}+\mathrm{BARF}]^{+}\right)$, but sodium removal dominates in this case. For the TPPB and carborane anions, essentially no proton transfer to yield the $[\mathrm{M}+\mathrm{Na}]^{+}$ion is observed. Peptide ion fragmentation, which yields products largely devoid of sodium ions, is noted for the BARF, TPPB, and carborane anions. The extent of peptide fragmentation associated with complexes comprised of these anions is less than that observed with the doubly protonated species (Figure 2) and protonated/lithiated species (Figure 3).

The results for the potassium-containing analogs of the bradykinin dications (i.e., $[\mathrm{RPPGFSPFR}+\mathrm{H}+\mathrm{K}]^{2+}$ ) are shown in Figure 5. Resonant excitation of the electrostatic complex formed with deprotonated BMSA anion and potassiated bradykinin, [RPPGFSPFR $+\mathrm{H}+\mathrm{K}+\mathrm{BMSA}]^{+}$, yielded both dissociation channels (i.e., the loss of the proton and the loss of the potassium cation) (Figure 5a). The removal of a proton is shown to be slightly more favorable than the removal of a potassium cation. The $\mathrm{PF}_{6}{ }^{-}$anion is the only WCA that exhibits some proton removal while the other WCAs (i.e., BARF, TPPB, and $\mathrm{CHB}_{11} \mathrm{Cl}_{11}{ }^{-}$anions) show no evidence for proton transfer (Figure 5b-e, respectively). Rather, these anions lead to a dominant potassium cation transfer product (viz., $[\mathrm{M}+\mathrm{H}]^{+}$) with far less peptide fragmentation than observed with the smaller cations. It is apparent that as the alkali cation size increases, the barrier for metal transfer decreases such that peptide cleavage becomes less competitive. In line with this observation, data collected with the cesiated peptide, $[\mathrm{RPPGFSPFR}+\mathrm{H}+\mathrm{Cs}]^{2+}$, showed exclusive cesium ion transfer with all WCAs. Even with the $[\mathrm{BMSA}-\mathrm{H}]^{-}$anion, cesium ion transfer is the predominant process, although proton transfer is also observed (see Supplemental Figure 1).

Effect of the Basic Residues on Sodium Cation Removal The competition between metal ion transfer and proton transfer is clearly dependent on the metal ion and proton affinities of the anion. The metal ion and proton affinities of the analyte ion also play roles in this competition. In practice, sodium ions are the most frequently encountered alkali ions in ESI experiments. We have, therefore, examined the role of the basic side-chain identity in affecting the competition between proton and sodium ion transfer. Electrostatic complexes between model peptides of the form $[\mathrm{XAXAXAA}+\mathrm{H}+\mathrm{Na}]^{2+}$, where $\mathrm{X}=\mathrm{Lys}$, His, or Arg, and deprotonated BMSA, $\mathrm{PF}_{6}{ }^{-}$, and $\mathrm{CHB}_{11} \mathrm{Cl}_{11}{ }^{-}$were studied (see Table 1). These reagent anions were chosen to represent anions of relatively high, intermediate, and low proton affinities, respectively. The BARF and TPPB anions are intermediate to $\mathrm{PF}_{6}{ }^{-}$and $\mathrm{CHB}_{11} \mathrm{Cl}_{11}{ }^{-}$.

Dissociation of the electrostatic complexes formed between the anions and the $[\mathrm{XAXAXAA}+\mathrm{H}+\mathrm{Na}]^{2+}$ model peptides showed very little peptide fragmentation, unlike those of bradykinin. This is likely due to the fact that the main dissociation channels observed with the sodium containing bradykinin complex were proline-related [45] cleavages and proline is absent in the model peptides. The information in the product spectra could, therefore, be summarized in tabular form. The spectra from which the table was generated are provided in Supplemental Figure S2. [KAKAKAA+H+Na] ${ }^{2+}$ and [HAHA $\mathrm{HAA}+\mathrm{H}+\mathrm{Na}]^{2+}$ complexes behaved similarly. Both reacted exclusively by proton transfer with $[\mathrm{BMSA}-\mathrm{H}]^{-}$and both reacted exclusively by sodium ion transfer with the carborane anion. Both proton and sodium ion transfer were observed with $\mathrm{PF}_{6}{ }^{-}$with proton transfer dominating in both cases. Dissociation of the electrostatic complexes and the dication $[\mathrm{RARARAA}+\mathrm{H}+\mathrm{Na}]^{2+}$ showed that the tendency for removal of a sodium cation was more favorable with [BMSA $-\mathrm{H}]^{-}$and $\mathrm{PF}_{6}{ }^{-}$anions than was observed for the other model peptides. Sodium ion transfer was the exclusive process for all of the carborane anion complexes. This greater tendency for sodium ion transfer from [RARARAA $+\mathrm{H}+\mathrm{Na}]^{2+}$ is attributed to the significantly greater proton affinity of arginine relative to those of lysine and histidine.

\section{Calculations}

A generic energy diagram for a case in which proton transfer from $[\mathrm{M}+\mathrm{H}+\mathrm{Na}]^{2+}$ to a reagent anion $\mathrm{A}^{-}$is favored thermodynamically over sodium ion transfer is given in Figure 6 . The blue arrows in Figure 6 represent the calculated values for the sodium cation affinity of the reagent anions, proton affinity of 


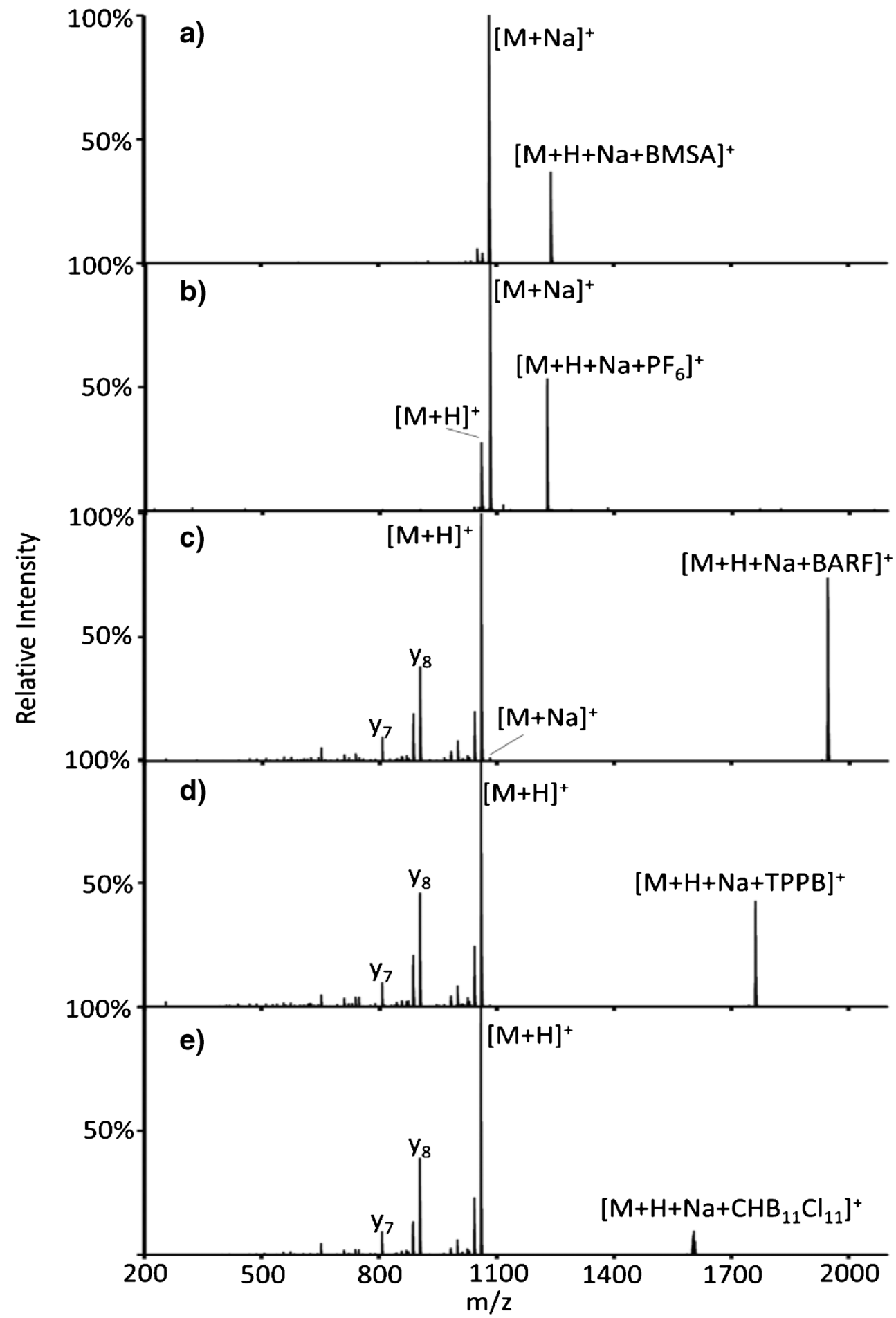

Figure 4. Resonant excitation of the complex between protonated and sodiated bradykinin $\left([\mathrm{RPPGFSPFR}+\mathrm{H}+\mathrm{Na}]^{2+}\right)$ and $(\mathrm{a})$ $\left[\mathrm{BMSA}-\mathrm{H}^{-}\right.$, (b) $\mathrm{PF}_{6}^{-}$, (c) $\mathrm{BARF}^{-}$, (d) $\mathrm{TPPB}^{-}$, and (e) $\mathrm{CHB}_{11} \mathrm{Cl}_{11}^{-}$

the reagent anions, sodium cation affinity of the peptides, and proton affinity of the peptides. These enthalpies have been estimated via DFT calculations of the various zero-point energies for the relevant reactants and products. The difference in the enthalpies for proton and sodium transfer has been estimated from the difference in zero-point energies for proton and sodium ion removal by the anion from the complex (viz.,
$\left.\Delta \Delta \mathrm{H} \approx \Delta \mathrm{E}=\mathrm{E}_{\mathrm{H}+\text { removal }}-\mathrm{E}_{\mathrm{Na}+\text { removal }}\right)$. The energies required to reach the respective transition states, $\mathrm{E}_{\mathrm{Na}+}{ }^{\neq}$and $\mathrm{E}_{\mathrm{H}+}{ }^{\neq}$, are indicated by green arrows.

Relatively simple model compounds that consisted of either two amino, two imidazole, or two guanidine groups linked by a three-carbon chain were used to simulate the peptides KAKAKAA, HAHAHAA, and RARARAA, respectively. 


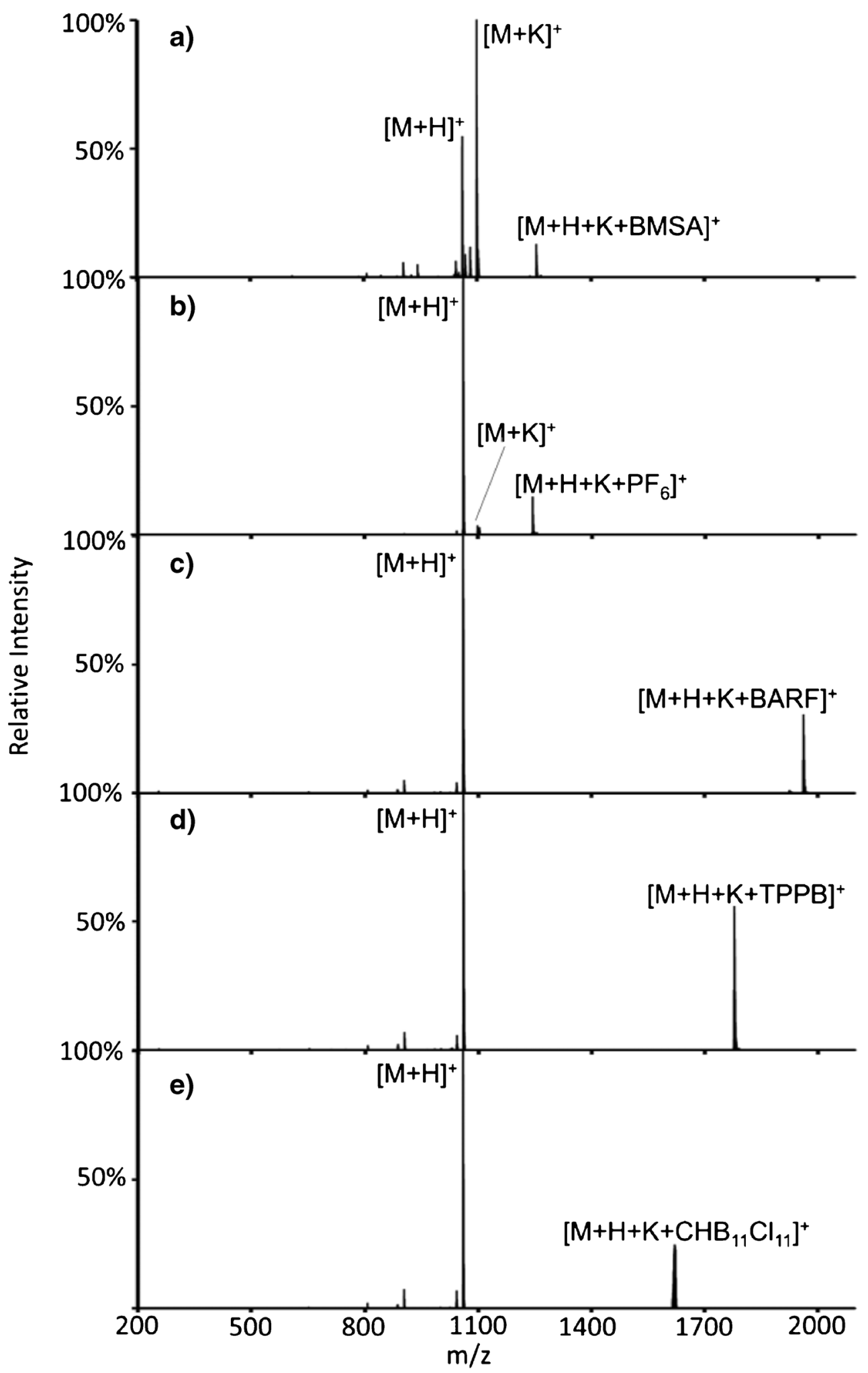

Figure 5. Resonant excitation of the complex between protonated and potassiated bradykinin $\left([\mathrm{RPPGFSPFR}+\mathrm{H}+\mathrm{K}]^{2+}\right)$ and $(\mathrm{a})$ $\left[\mathrm{BMSA}-\mathrm{H}^{-}\right.$, (b) $\mathrm{PF}_{6}^{-}$, (c) $\mathrm{BARF}^{-}$, (d) $\mathrm{TPPB}^{-}$, and (e) $\mathrm{CHB}_{11} \mathrm{Cl}_{11}^{-}$

The peptide KAKAKAA's sodium and proton affinities were also calculated to indicate how closely the small model matched the peptide. The calculated $\Delta \Delta \mathrm{H}$ values are listed in
Table 2. The $\Delta \Delta \mathrm{H}$ values for the complexes of the diamine, diimidazole, and KAKAKAA with deprotonated BMSA are negative indicating that proton removal is thermodynamically 
Table 1. Observed Relative Partitioning Between Proton Transfer Versus Sodium Ion Transfer from the Complexes of $\left[\mathrm{BMSA}^{-\mathrm{H}}\right]^{-}, \mathrm{PF}_{6}{ }^{-}$, and $\mathrm{CHB}_{11} \mathrm{Cl}_{11}{ }^{-}$with the Three [XAXAXAA $+\mathrm{H}+\mathrm{Na}]^{2+}$ Model Peptides

$\mathrm{Na}^{+}$versus $\mathrm{H}^{+}$transfer

\begin{tabular}{|c|c|c|c|c|c|c|}
\hline \multirow{2}{*}{$\begin{array}{l}\text { Analyte } \\
\text { Pathway Anion }\end{array}$} & \multicolumn{2}{|c|}{$\left[\mathrm{KAKAKAA}^{+}+\mathrm{H}+\mathrm{Na}\right]^{2+}$} & \multicolumn{2}{|c|}{$[\mathrm{HAHAHAA}+\mathrm{H}+\mathrm{Na}]^{2+}$} & \multicolumn{2}{|c|}{$[\mathrm{RARARAA}+\mathrm{H}+\mathrm{Na}]^{2+}$} \\
\hline & $\mathrm{Na}^{+}$removal & $\mathrm{H}^{+}$removal & $\mathrm{Na}^{+}$removal & $\mathrm{H}^{+}$removal & $\mathrm{Na}^{+}$removal & $\mathrm{H}^{+}$removal \\
\hline [BMSA-H $^{-}$ & 0 & 100 & 0 & 100 & 10 & 90 \\
\hline $\mathrm{PF}_{6}^{-}$ & 20 & 80 & 10 & 90 & 85 & 15 \\
\hline $\mathrm{CHB}_{11} \mathrm{Cl}_{11}^{-}$ & 100 & 0 & 100 & 0 & 100 & 0 \\
\hline
\end{tabular}

preferred over sodium removal. The positive $\Delta \Delta \mathrm{H}$ value for the diguanidine case, on the other hand, indicates that sodium ion transfer to deprotonated BMSA is thermodynamically favored. The only peptide ion observed in this study to transfer the sodium ion to $[\mathrm{BMSA}-\mathrm{H}]^{-}$was $[\mathrm{RARARAA}+\mathrm{H}+\mathrm{Na}]^{2+}$. However, proton transfer was the dominant process. This is one of several results that suggest that, in general, sodium ion transfer is kinetically disfavored relative to proton transfer unless $\Delta \Delta \mathrm{H}$ strongly favors sodium ion transfer. The kinetic factor can arise from a higher transition state barrier and/or a tighter transition state associated with sodium ion transfer (see below).

The positive $\Delta \Delta \mathrm{H}$ values calculated for the $\mathrm{PF}_{6}{ }^{-}$anion indicates that the sodium cation transfer channel is thermodynamically favored with all of the calculated systems with the largest $\Delta \Delta \mathrm{H}$ value obtained for the diguanidine system. Indeed, sodium ion transfer is observed with all of the model peptide ions but is the dominant process only for [RARA $\mathrm{RAA}+\mathrm{H}+\mathrm{Na}]^{2+}$. These findings again point to one or more differences in the transition states for proton versus sodium transfer that disfavor sodium ion transfer. The calculations involving the carborane anion show the highest $\Delta \Delta \mathrm{H}$ values favoring sodium ion transfer for all systems examined and is the only anion of the three that leads to essentially exclusive sodium ion transfer in each case.

The $\Delta \Delta \mathrm{H}$ values in Table 2 for the diamine, diimidizole, and diguanidine systems were generated from the calculated $\Delta \mathrm{H}$ values for each of the processes (i.e., $\mathrm{Na}^{+}$and $\mathrm{H}^{+}$removal) listed in Table 3. As expected, the $\Delta \mathrm{H}$ values for the diamine and diimidizole systems are similar given the similar proton

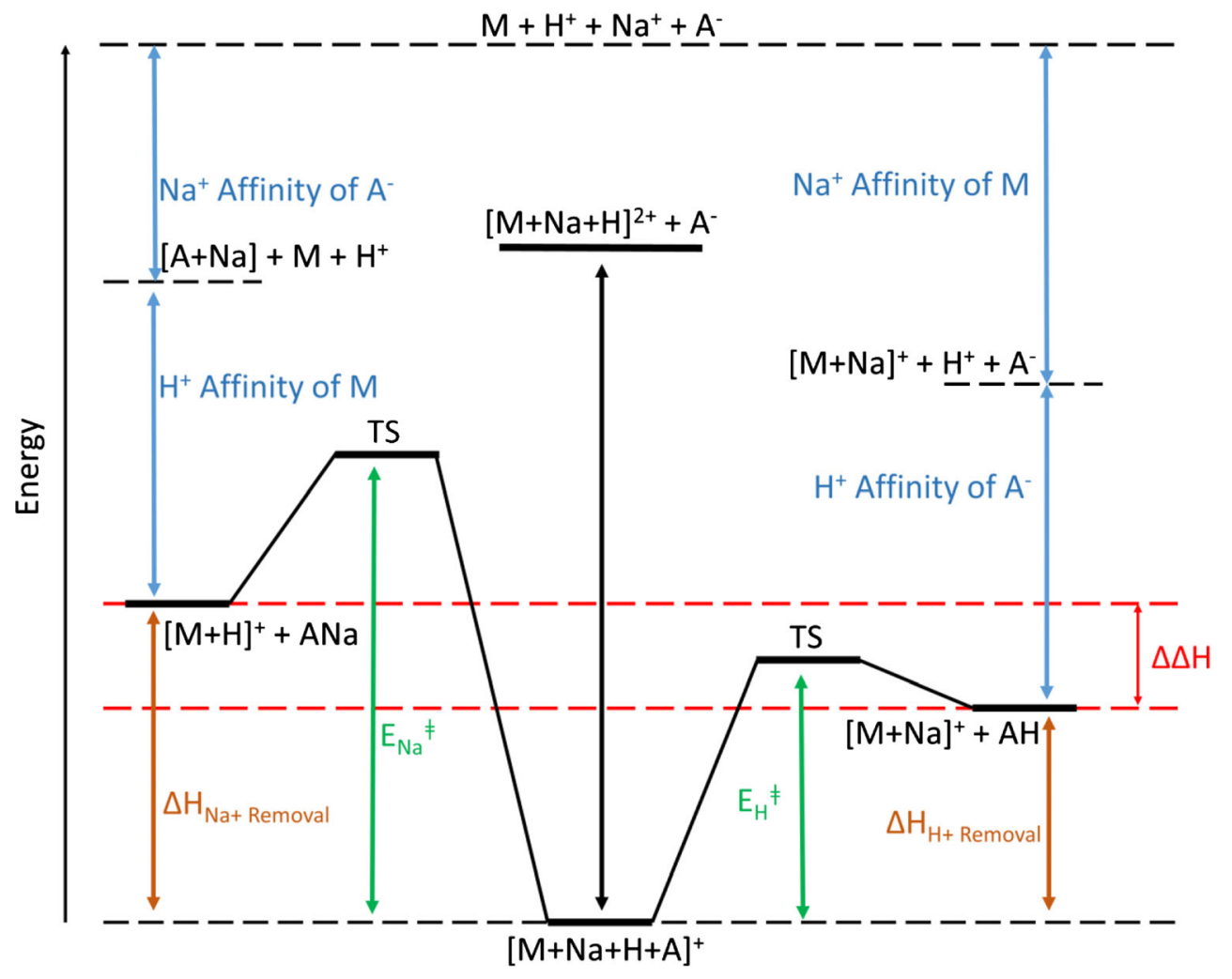

Figure 6. Energy diagram depicting the two dissociation channels from the ion/ion complex that lead to either proton transfer or sodium ion transfer. The channel on the left illustrates the removal of the sodium from $\mathrm{M}$ by the reagent resulting in a protonated analyte, whereas the channel on the right illustrates the removal of the proton by the reagent resulting in a sodiated analyte 
Table 2. Calculated Energy Difference Between Proton Removal and Sodium Removal on Model Systems or the Peptide KAKAKAA by [BMSA - H] ${ }^{-}$, $\mathrm{PF}_{6}{ }^{-}$, or $\mathrm{CHB}_{11} \mathrm{Cl}_{11}{ }^{-}$. The model Systems Were Two Amines, Two Imidazole Rings, or Two Guanidines Linked by a Three-Carbon Chain

\begin{tabular}{lcccc}
\hline$\Delta \Delta \mathrm{H} \approx \Delta \mathrm{E}_{\mathrm{H}+\text { removal }-\mathrm{Na}+\text { removal }}(\mathrm{ZPE}) \mathrm{kcal} / \mathrm{mol}$ & & \\
\hline Analyte Anion & Diamine & Diimidizole & Diguanidine & KAKAKAA \\
\hline$[\mathrm{BMSA}-\mathrm{H}]^{-}$ & -10.69 & -6.13 & 10.36 & -4.23 \\
$\mathrm{PF}_{6}{ }^{-}$ & 14.68 & 19.23 & 35.72 & 21.12 \\
$\mathrm{CHB}_{11} \mathrm{Cl}_{11}{ }^{-}$ & 35.16 & 39.72 & 56.21 & 41.60 \\
\hline
\end{tabular}

affinities of these basic sites. Table 3 shows that the $\Delta \Delta \mathrm{H}$ value trends in Table 2 arise from opposing trends in $\Delta \mathrm{H}$ values for the two cations. That is, the $\Delta \mathrm{H}$ values for sodium cation removal decrease in going from [BMSA $\mathrm{H}]^{-}$to the carborane anion whereas the $\Delta \mathrm{H}$ values for proton transfer increase in going from [BMSA $-\mathrm{H}]^{-}$to the carborane anion.

Tables 2 and 3 provide calculated thermodynamic values relevant to Figure 6. As the competition between proton transfer and sodium ion transfer upon activation of the ion/ion complex is under kinetic control, the $\mathrm{E}_{\mathrm{H}^{+}} \neq$and $\mathrm{E}_{\mathrm{Na}+}{ }^{\neq}$values and entropies associated with the transition states are key to the outcome to the ion transfer competition. These factors are less readily determined than the thermodynamic values due, in part, to mechanistic uncertainties (e.g., location of the transition state). However, given the experimental evidence for differences in transition state barriers, two systems, [diamine $\left.+\mathrm{H}^{+}+\mathrm{Na}^{+}\right]^{2+} /$ $\mathrm{CHB}_{11} \mathrm{Cl}_{11}{ }^{-}$and $[\text {diamine }+\mathrm{H}+\mathrm{Na}]^{2+} / \mathrm{PF}_{6}{ }^{-}$, were examined more closely by calculating approximate transition state energies. The $[\text { diamine }+\mathrm{H}+\mathrm{Na}]^{2+} / \mathrm{CHB}_{11} \mathrm{Cl}_{11}{ }^{-}$system was chosen because the carborane anion was clearly shown to be the anion most likely to remove alkali ions experimentally and was calculated to strongly favor sodium transfer on thermodynamic grounds. The [diamine $+\mathrm{H}+\mathrm{Na}]^{2+} / \mathrm{PF}_{6}{ }^{-}$ system was selected as an example where sodium ion transfer was calculated to be favored thermodynamically but the KAKAKAA experiment showed proton transfer to be more competitive (although sodium transfer was also observed). In the case of $[\text { diamine }+\mathrm{H}+\mathrm{Na}]^{2+} / \mathrm{CHB}_{11} \mathrm{Cl}_{11}{ }^{-}$,
$\mathrm{E}_{\mathrm{Na}+} \neq$ is estimated to be $49.12 \mathrm{kcal} / \mathrm{mol}$, which is much higher than $\Delta \mathrm{H}_{\mathrm{Na}+}$ transfer, calculated to be $19.29 \mathrm{kcal} / \mathrm{mol}$ (see Table 3). Nevertheless, $\mathrm{E}_{\mathrm{Na}^{+}}{ }^{\neq}$remains lower than $\Delta \mathrm{H}_{\mathrm{H}+}$ transfer, calculated to be $54.45 \mathrm{kcal} / \mathrm{mol}$. Therefore, regardless of the magnitude of $\mathrm{E}_{\mathrm{H}^{+}}{ }^{\neq}$, which must be greater than or equal to $54.45 \mathrm{kcal} / \mathrm{mol}$, the barrier to sodium transfer is lower for the carborane anion than the barrier to proton transfer. The calculations indicate that the barriers for both proton and sodium ion transfer are relatively high for the carborane anion, which likely underlies the observation of peptide ion fragmentation for the $[\text { bradykinin }+2 \mathrm{H}]^{2+} / \mathrm{CHB}_{11} \mathrm{Cl}_{11}{ }^{-}$(Figure $\left.2 \mathrm{e}\right)$, [bradykinin $+\mathrm{H}+\mathrm{Li}]^{2+} / \mathrm{CHB}_{11} \mathrm{Cl}_{11}{ }^{-}$(Figure $3 \mathrm{e}$ ), and [bradykinin $+\mathrm{H}+\mathrm{Na}]^{2+} / \mathrm{CHB}_{11} \mathrm{Cl}_{11}{ }^{-}$(Figure $4 \mathrm{e}$ ) cases. Calculations performed by Paizs and Suhai have shown that dissociation energies for an amide protonated, nonarginine containing peptide to $b_{x}-y_{z}$ ions range from $\sim 25-$ $40 \mathrm{kcal} / \mathrm{mol}$ [45]. Hence, peptide bond cleavage can be competitive with ion transfer from the carborane complexes and might also arise from consecutive fragmentation. This is also presumably underlies similar behavior with the BARF and TPPB anion data, although no calculations were performed for these WCAs.

The $[\text { diamine }+\mathrm{H}+\mathrm{Na}]^{2+} / \mathrm{PF}_{6}{ }^{-}$calculation yielded an estimate of $32.16 \mathrm{kcal} / \mathrm{mol}$ for $\mathrm{E}_{\mathrm{Na}+}{ }^{\neq}$and $67.83 \mathrm{kcal} / \mathrm{mol}$ for $\mathrm{E}_{\mathrm{H}^{+}} \neq$. The $\mathrm{E}_{\mathrm{Na}^{+}}{ }^{\neq}$value is lower than the $\Delta \mathrm{H}_{\mathrm{H}+}$ transfer value, which was calculated to be $36.50 \mathrm{kcal} / \mathrm{mol}$. In contrast to the case with the carborane anion, which showed no evidence for proton transfer from the $[\mathrm{KAKAKAA}+\mathrm{H}+\mathrm{Na}]^{2+}$ ion, the $\mathrm{PF}_{6}{ }^{-}$anion showed both proton transfer and sodium ion transfer with the former being favored. The calculated barriers for sodium and proton transfer are inconsistent with this observation as $\mathrm{E}_{\mathrm{H}+} \neq$ is much greater than $\mathrm{E}_{\mathrm{Na}+}{ }^{\neq}$. Even if tunneling [46] were to take place in the case of proton transfer, sodium ion transfer would still be favored purely on energetic grounds since $\mathrm{E}_{\mathrm{Na}+}{ }^{\neq}<\Delta \mathrm{H}_{\mathrm{H}+}$. Provided the diamine is a reliable model for KAKAKAA and the calculated values are even roughly accurate, this observation strongly suggests that sodium ion transfer is significantly slower than proton transfer. This apparently underlies why sodium/metal ion transfer must be strongly favored thermodynamically in order to overcome a kinetic disadvantage relative to proton transfer.

Table 3. Calculated $\Delta \mathrm{H}$ Energies Required to Transfer a Sodium Cation or a Proton from the Diamine, Diimidizole, or Diguanidine Model Systems by [BMSA $\mathrm{H}^{-}, \mathrm{PF}_{6}^{-}$, or $\mathrm{CHB}_{11} \mathrm{Cl}_{11}$

$\Delta \mathrm{H}$ for cation transfer from ion/ion complex $(\mathrm{kcal} / \mathrm{mol})$

\begin{tabular}{|c|c|c|c|c|c|c|}
\hline \multirow{2}{*}{$\begin{array}{l}\text { Analyte } \\
\Delta \mathrm{H}_{\text {cation }} \text { Anion }\end{array}$} & \multicolumn{2}{|l|}{ Diamine } & \multicolumn{2}{|l|}{ Diimidizole } & \multicolumn{2}{|l|}{ Diguanidine } \\
\hline & $\mathrm{Na}^{+}$removal & $\mathrm{H}^{+}$removal & $\mathrm{Na}^{+}$removal & $\mathrm{H}^{+}$removal & $\mathrm{Na}^{+}$removal & $\mathrm{H}^{+}$removal \\
\hline$[\mathrm{BMSA}-\mathrm{H}]^{-}$ & 39.05 & 28.37 & 34.84 & 28.71 & 36.75 & 47.14 \\
\hline $\mathrm{PF}_{6}^{-}$ & 21.82 & 36.50 & 22.09 & 41.32 & 24.42 & 60.14 \\
\hline $\mathrm{CHB}_{11} \mathrm{Cl}_{11}^{-}$ & 19.29 & 54.45 & 17.92 & 57.64 & 2.61 & 58.82 \\
\hline
\end{tabular}




\section{Conclusions}

Selective and complete alkali ion metal cation removal has been demonstrated using ion/ion reactions with a carborane anion. Resonant excitation of complexes comprised of a carborane anion and a peptide containing an adducted alkali metal cation results in selective removal of the metal cation adduct with no evidence for any proton transfer. The carborane anion was the only reagent to show no evidence for proton transfer for any of the metal ions studied. Resonant excitation of the complexes of a peptide adducted with metal cations and the anions studied showed the selectivity for metal ion transfer to follow the order $\mathrm{CHB}_{11} \mathrm{Cl}_{11}{ }^{-}>\mathrm{TBBP}>\mathrm{BARF}>\mathrm{PF}_{6}{ }^{-}>[\mathrm{BMSA}-\mathrm{H}]^{-}$. Density functional theory calculations involving model dications and the reagent anions $\mathrm{CHB}_{11} \mathrm{Cl}_{11}{ }^{-}, \mathrm{PF}_{6}{ }^{-}$, and [BMSA $\left.-\mathrm{H}\right]^{-}$indicated that metal ion transfer is strongly favored thermodynamically for the carborane anion. The calculations also suggest that proton transfer is inherently a faster process because it is often observed with other reagent anions for which metal ion transfer is preferred thermodynamically, although not as much as the carborane anion. Therefore, these results demonstrate that the $\mathrm{CHB}_{11} \mathrm{Cl}_{11}{ }^{-}$is the most reliable reagent for the removal of metal cations from peptide ions with mixtures of excess protons and alkali metal cations.

\section{Acknowledgments}

This material is based upon work supported by the U.S. Department of Energy, Office of Science, Office of Basic Energy Sciences under Award Number FG02-00ER15105. Professor Timothy S. Zwier is acknowledged for loaning cluster space for calculations.

\section{References}

1. Cech, N.B., Enke, C.G.: Practical implications of some recent studies in electrospray ionization fundamentals. Mass Spectrom. Rev. 20, 362-387 (2001)

2. Wang, G., Cole, R.B.: Effect of solution ionic strength on analyte charge state distributions in positive and negative ion electrospray mass spectrometry. Anal. Chem. 66, 3702-3708 (1994)

3. Iavarone, A.T., Udekwu, O.A., Williams, E.R.: Buffer loading for counteracting metal salt-induced signal suppression in electrospray ionization. Anal. Chem. 76, 3944-3950 (2004)

4. Feng, W.Y., Gronert, S., Fletcher, K.A., Warres, A., Lebrilla, C.: The mechanism of C-terminal fragmentations in alkali metal ion complexes of peptides. Int. J. Mass Spectrom. 222, 117-134 (2003)

5. Teesch, L.M., Adams, J.: Fragmentations of gas-phase complexes between alkali metal ions and peptides: metal ion binding to carbonyl oxygens and other neutral functional groups. J. Am. Chem. Soc. 112, 4110-4120 (1990)

6. Jurascheck, R., Dulcks, T., Karas, M.: Nanoelectrospray- more than just a minimized-flow electrospray ionization source. J. Am. Soc. Mass Spectrom. 10, 300-308 (1999)

7. Annesley, T.M.: Ion suppression in mass spectrometry. Clin. Chem. 49, 1041-1044 (2003)

8. Stanova, A., Marak, J.: Buffer salt effects in off-line coupling of capillary electrophoresis and mass spectrometry. Electrophoresis 35, 1268-1274 (2014)

9. Jiang, Y., Hofstadler, S.A.: A highly efficient ad automated method of purifying and desalting PCR products for analysis by electrospray ionization mass spectrometry. Anal. Biochem. 316, 50-57 (2003)
10. Gilar, M., Bouvier, E.S.P., Compton, B.J.: Advances in sample preparation in electromigration, chromatographic and mass spectrometric separation methods. J. Chromatogr. A 909, 111-135 (2001)

11. Jakubowski, J.A., Hatcher, N.G., Sweedler, J.V.: Online microdialysisdynamic nanoelectrospray ionization-mass spectrometry for monitoring neuropeptide secretion. J. Mass Spectrom. 40, 924-931 (2005)

12. Chen, Y., Mori, M., Pastusek, A.C., Schug, K.A., Dasgupta, P.K.: On-line electrodialtytic salt removal in electrospray ionization mass spectrometry of proteins. Anal. Chem. 83, 1015-1021 (2011)

13. Kharlamova, A., Prentice, B.M., Huang, T., McLuckey, S.A.: Electrospray droplet exposure to gaseous acids for reduction of metal counter-ions in nucleic acid ions. Int. J. Mass Spectrom. 300, 158-166 (2011)

14. Apffel, A., Fischer, S., Goldber, G., Goodley, P.C., Kuhlmann, F.E.: Enhanced sensitivity for peptide mapping with electrospray liquid chromatography-mass spectrometry in the presence of signal suppression due to trifluoroacetic acid-containing mobile phases. J. Chromatogr. A 712, 177-190 (1995)

15. McLuckey, S.A., Van Berkel, G.J., Glish, G.L.: Reactions of dimethylamine with multiply charged ions of cytochrome $c$. J. Am. Chem. Soc. 112, 5668-5670 (1990)

16. Williams, E.R.: Proton transfer reactivity of large multiply charged ions. J. Mass Spectrom. 31, 831-842 (1996)

17. McLuckey, S.A., Huang, T.-Y.: Ion/ion reactions: new chemistry for analytical MS. Anal. Chem. 81, 8669-8676 (2009)

18. McLuckey, S.A., Mentinova, M.: Ion/neutral, ion/electron, ion/photon, and ion/ion interactions in tandem mass spectrometry: Do we need them all? Are they enough? J. Am. Soc. Mass Spectrom. 22, 3-12 (2011)

19. Stephenson, J.L., McLuckey, S.A.: Ion/ion reactions in the gas phase: proton transfer reactions involving multiply-charged proteins. J. Am. Chem. Soc. 118, 7390-7397 (1996)

20. Stephenson, J.L., McLuckey, S.A.: Ion/ion proton transfer reactions for protein mixture analysis. Anal. Chem. 68, 4026-4032 (1996)

21. Syka, J.E.P., Coon, J.J., Schroeder, M.J., Shabanowitz, J., Hunt, D.F.: Peptide and protein sequence analysis by electron transfer dissociation mass spectrometry. Proc. Natl. Acad. Sci. U. S. A. 101, 9528-9533 (2004)

22. Coon, J.J., Shabanowitz, J., Hunt, D.F., Syka, J.E.P.: Electron transfer dissociation of peptide anions. J. Am. Soc. Mass Spectrom. 16, 880-882 (2005)

23. Pilo, A.L., McLuckey, S.A.: Oxidation of methionine residues in polypeptide ions via gas-phase ion/ion chemistry. J. Am. Chem. Soc. Mass Spectrom. 25, 1049-1057 (2014)

24. Newton, K.A., McLuckey, S.A.: Gas-phase peptide/protein cationizing agent switching via ion/ion reactions. J. Am. Chem. Soc. 125, 12404 12405 (2003)

25. Gunawardena, H.P., O'Hair, R.A.J., McLuckey, S.A.: Selective disulfide bond cleavage in gold(I) cationized polypeptide ions formed via gas-phase ion/ion cation switching. J. Proteome Res. 5, 2087-2092 (2006)

26. Han, H., McLuckey, S.A.: Selective covalent bond formation in polypeptide ions via gas-phase ion/ion reaction chemistry. J. Am. Chem. Soc. 131, 12884-12885 (2009)

27. Mentinova, M., McLuckey, S.A.: Covalent modification of gaseous peptide ions with N-hydroxysuccinimide ester reagent ions. J. Am. Chem. Soc. 132, 18248-18257 (2010)

28. Prentice, B.M., Gilbert, J.D., Stutzman, J.R., Forrest, W.P., McLuckey, S.A.: Gas-phase reactivity of carboxylic acid functional groups with carbodiimides. J. Am. Soc. Mass Spectrom. 24, 30-37 (2013)

29. He, M., Emory, J.F., McLuckey, S.A.: Reagent anions for charge inversion of polypeptide/protein cations in the gas phase. Anal. Chem. 77, 31733182 (2005)

30. Stutzman, J.R., Luongo, C.A., McLuckey, S.A.: Covalent and noncovalent binding in the ion/ion charge inversion of peptide cations with benzenedisulfonic acid anions. J. Mass Spectrom. 47, 669-675 (2012)

31. Newton, K.A., He, M., Amunugama, R., McLuckey, S.A.: Selective cation removal from gaseous polypeptide ions: proton versus sodium ion abstraction via ion/ion reactions. Phys. Chem. Chem. Phys. 6, 2710-2717 (2004)

32. Krossing, I., Raabe, I.: Noncoordinating anions - fact or fiction? A survey of likely candidates. Angew. Chem. Int. Ed. 43, 2066-2090 (2004)

33. Strauss, S.H.: The search for larger and more weakly coordinating anions. Chem. Rev. 93, 927-942 (1993)

34. Reed, C.A.: Carborane acids. New "strong yet gentle" acids for organic and inorganic chemistry. Chem. Commun. 13, 1669-1677 (2005)

35. Xia, Y., Wu, J., Londry, F.A., Hager, J.W., McLuckey, S.A.: Mutual storage mode ion/ion reactions in hybrid linear ion trap. J. Am. Soc. Mass Spectrom. 16, 71-81 (2005) 
36. Liang, W., Xia, Y., McLuckey, S.A.: Alternately pulsed nano-electrospray ionization/atmospheric pressure chemical ionization for ion/ion reactions in an electrodynamic ion trap. Anal. Chem. 78, 3208-3212 (2006)

37. Londry, F.A., Hager, J.W.: Mass selective axial ion ejection from a linear quadrupole ion trap. J. Am. Chem. Soc. 14, 1130-1147 (2003)

38. Frisch, M.J., Trucks, G.W., Schlegel, H.B., Scuseria, G.E., Robb, M.A., Cheeseman, J.R., Scalmani, G., Barone, V., Mennucci, B., Petersson, G.A., Nakatsuji, H., Caricato, M., Li, X., Hratchian, H.P., Izmaylov, A.F., Bloino, J., Zheng, G., Sonnenberg, J.L., Hada, M., Ehara, M., Toyota, K., Fukuda, R., Hasegawa, J., Ishida, M., Nakajima, T., Honda, Y., Kitao, O., Nakai, H., Vreven, T., Montgomery, J.A. Jr., Peralta, J.E., Ogliaro, F., Bearpark, M., Heyd, J J., Brothers, E., Kudin, K.N., Staroverov, V.N., Kobayashi, R., Normand, J., Raghavachari, K., Rendell, A., Burant, J.C., Iyengar, S.S., Tomasi, J., Cossi, M., Rega, N., Millam, N.J., Klene, M., Knox, J.E., Cross, J.B., Bakken, V., Adamo, C., Jaramillo, J., Gomperts, R., Stratmann, R.E., Yazyev, O., Austin, A.J., Cammi, R., Pomelli, C., Ochterski, J.W., Martin, R.L., Morokuma, K., Zakrzewski, V.G., Voth, G.A., Salvador, P., Dannenberg, J.J., Dapprich, S., Daniels, A.D., Farkas, Ö., Foresman, J.B., Ortiz, J.V., Cioslowski, J., Fox, D.J.: Gaussian, Inc., Wallingford CT, (2009)

39. Meyer, M.M., Wang, X.B., Reed, C.A., Wang, L.S., Kass, S.R.: Investigating the weak to evaluate the strong: an experimental determination of the electron binding energy of carborane anions and the gas phase acidity of carborane acids. J. Am. Chem. Soc. 131, 18050-18051 (2009)

40. Mohamadi, F., Richards, N.G.J., Guida, W.C., Liskamp, R., Lipton, M., Caufield, C., Chang, G., Hendrickson, T., Still, W.C.: Macromodel-an integrated software system for modeling organic and bioorganic molecules using molecular mechanics. J. Comput. Chem. 11, 440-467 (1990)
41. Weiner, P.K., Kollman, P.A.: AMBER: assisted model building with energy refinement. A general program for modeling molecules and their interactions. J. Comput. Chem. 2, 287-303 (1981)

42. Behn, A., Zimmerman, P.M., Bell, A.T., Head-Gordon, M.: Efficient exploration of reaction paths via a freezing string method. J. Chem. Phys. 135, 224108-224116 (2011)

43. Shao, Y., Molnar, L.F., Jung, J., Kussmann, J., Ochsenfeld, C., Brown, S.T., Gilbert, A.T.B., Slipchenko, L.V., Levchenko, S.V., O'Neill, D.P., DiStasio, R.A., Lochan, R.C., Wang, T., Beran, G.J.O., Besley, N.A., Herbert, J.M., Lin, C.Y., Voorhis, T.V., Chien, S.H., Sodt, A., Steele, R.P., Rassolov, V.A., Maslen, P.E., Korambath, P.P., Adamson, R.D., Austin, B., Baker, B., Byrd, E.F.C., Daschel, H., Doerksen, R.J., Dreuw, A., Dunietz, B.D., Dutoi, A.D., Furlani, T.R., Gwaltney, S.R., Heyden, A., Hirata, S., Hsu, C.P., Kedziora, G., Khaliullin, R.Z., Klunzinger, P., Lee, A.M., Lee, M.S., Liang, W.Z., Lotan, I., Nair, N., Peters, B., Proynov, E.I., Pieniazek, P.A., Rhee, Y.M., Ritchie, J., Rosta, E., Sherrill, C.D., Simmonett, A.C., Subotnik, J.E., Woodcock III, H.L., Zhang, W., Bell, A.T., Chakraborty, A.K., Chipman, D.M., Keil, F.J., Warshel, A., Hehre, W.J., Schaefer III, H.F., Kong, J., Krylov, A.I., Gill, P.M.W., Head-Gordon, M.: Advances in quantum chemical methods and algorithms in the Q-Chem 3.0 program package. Phys. Chem. Chem. Phys. 8, 3172-3191 (2006)

44. Reed, C.A.: $\mathrm{H}^{+}, \mathrm{CH}_{3}{ }^{+}$and $\mathrm{R}_{3} \mathrm{Si}^{+}$carborane reagents: when triflates fail. Acc. Chem. Res. 43, 121-128 and supporting information (2010).

45. Paizs, B., Suhai, S.: Fragmentation pathways of protonated peptides. Mass Spectrom. Rev. 24, 508-548 (2004)

46. Grunwald, E.: Ultra-fast proton transfer reactions. In: Streitwieser, S.G., Taft, A., R.W. (eds.) Progress in Physical Organic Chemistry, Cohen, Vol. 3, pp. 317-358 (1965) 